\title{
Development of Islamic Education Evaluation System
}

\author{
Siti Kholidatur Rodiyah \\ Universitas Sunan Giri Surabaya \\ kholidaturrodiyah@gmail.com
}

\begin{abstract}
Education is essentially a change of knowledge, skills, attitudes and desirable behavior in students. Designing evaluation tools is one step that should not be left behind in learning planning and design. Through proper evaluation not only can determine the success of students achieving learning goals, but also at the same time can see the effectiveness of planned design programs.
\end{abstract}

Keyword : Development, Islamic Education, Evaluation System

\section{INTRODUCTION}

Guba and Lincoln define evaluation as a process of giving consideration to the value and meaning of something being considered (evaluation) (Sanjaya, 2008). While according to Oemar Hamalik (2011) evaluation is an ongoing process of gathering and interpreting information to assess the decisions made in designing a teaching system(Hamalik, 2011).

The formula has three evaluation characteristics. First, evaluation is a process that continually begins before teaching is carried out until the end of teaching.

Second, the evaluation process is always directed towards a specific goal, which is to get answers about how to improve teaching.

Third, evaluation requires the use of accurate and meaningful measurement tools to gather information needed to make decisions. As such, evaluation is a process which involves gathering information that allows to determine the level of progress of teaching and how to do good in the future.

\section{DISCUSSION}

\section{Function and Purpose of Evaluation}

Evaluation generally contains the following functions and objectives(Hamalik, 2011):

1. To determine the rate of progress or student learning outcomes.

2. To place students into teaching and learning situations that are appropriate and compatible with the level of ability, interest, and various characteristics possessed by each student.

3. To get to know the background of students (Psychological, physical, and environment), which is useful, both in relation to the second function and to determine the causes of students' learning difficulties.

4. As feedback for teachers who in turn can be used to improve teaching and learning andprograms remedial for students. 
5. Evaluation functions as feedback for all parties concerned with education in the school (Sanjaya, 2014).

\section{Types of Evaluations}

1. a.evaluation Summative, which is to determine the success rate of student learning outcomes.

2. b. Placement evaluation, i.e. placing students in harmonious teaching and learning situations.

3. c. Diagnostic evaluation, to help students overcome the learning difficulties they face.

4. d.evaluation Formative, to improve the teaching and learning process. That is done during the learning process to see the progress of student learning.

\section{Evaluation Principle}

In order for the evaluation to be carried out as planned, theevaluatorsmust follow the evaluation principles that have been determined, namely:

1. The principle of cohesiveness

In the assessment activities must pay attention to instructional objectives and teaching materials taught to students, so that each item made must not come out and deviate from aspects of the teaching material.

2. The Principle of Completeness

The assessment must be carried out thoroughly in accordance with the objectives of the assessment and the scope of the teaching material to be disclosed.

3. c. The Principle of Sustainability

This principle of sustainability implies that in order to obtain an adequate understanding of students, an ongoing evaluation program is needed.

4. Principle of Objectivity

Evaluations conducted by teachers must be carried out appropriately based on objective data on student learning progress, not based on teacher observations and subjective considerations.

5. Principle of Relevance

With the results of the evaluation, decision making assessments must be based on data relevant to the purpose of the assessment.

6. Principle of Regularity

In conducting an evaluation, we must know and pay attention to the evaluation procedures and steps that should be carried out. 


\section{Evaluation Techniques}

1. Techniques for Assessing Behavior Change in the Long Term There are three techniques that can be used, namely:

a. Direct observation, the way samples are taken from students and observed directly.

b. Indirect measurement, Measuring changes in living standards, quality of life, social awareness and participation in society.

c. Measurement with the help of others. All the sociological techniques of interviews and questionnaires can be used to find out the lifestyle of students.

2. Teaching Final Evaluation Techniques

Evaluation techniques are implemented at the end of teaching which include evaluations as follows:

a. Reproductive Skill Evaluation Techniques

1) Cognitive aspects, for example solving familiar problems in order to determine accuracy and speed.

2) Psychomotor aspects, with action tests there are implementation of real tasks or simulations objectively.

3) Reactive aspects, carried out directly with objective observation.

4) Interactive aspects, by calculating the frequency of habits and ways that are good in certain conditions.

b. Productive Skills Evaluation Techniques

1) Cognitive aspects, solving unfamiliar problems and uncomplicated solutions.

2) Psychomotor aspects, productive tasks that require strategic planning.

3) The reactive aspect, directly observing the community value system in its actions outside of school.

4) Interactive aspects, with observation of interactive skills in real social conditions or simulations continued to study planning.

3. Techniques to Assess Knowledge

a. Techniques to assess aspects of recognition (recognition)

b. You do this by giving multiple choice questions, which require students to do the correct identification.

c. Techniques for evaluating aspects of recall (recall)

d. How to direct questions to reveal answers.

e. Techniques for evaluating aspects of comprehension. The way to do this is by asking questions to identify true and false statements in the form of essays. 


\section{TEST}

\section{Learning Success Test}

Learning success test or Benchmark Reference (PAP) is a test consisting of items that directly measure behavior in the learning process. The types of tests used are (Sanjaya, 2008):

1. Prerequisite test (entery behavior test)

This test is used when the teacher wants to measure what students already have certain abilities as a condition for having other abilities.

2. Initial Test (pre test)

The initial test is a test used to measure how far students already have the ability regarding things to be learned.

3. Final Test (post test)

The final test is a test used to measure whether students have mastered certain competencies as formulated in the learning indicators.

4. Measuring Progress (progress test)

This test is given incidentally while students are in the process of learning a unit of study.

\section{Development of Success Measuring Tests}

To develop a test to measure success there are several things that must be considered, namely:

1. Test items derived from indicators of learning outcomes.

2. Test items must be oriented towards learning outcomes.

3. The test items need to explain under what conditions learning outcomes can be demonstrated.

4. Each indicator of learning outcomes should be arranged in more than one test item.

5. The test should be arranged in various types of items adjusted to the indicators of learning outcomes.

\section{Test Criteria}

As a measurement tool in the evaluation process, the test must have the following criteria:

1. Validity Criteria

Tests as a measuring instrument are said to have validity if they can measure what they want to measure. For example, if the teacher wants to know the students' understanding of certain material, then the test questions also contain the material and not other material. 
2. Reliability Criteria

The test is said to have reliability if it can produce consistent information. For example a test is given to a group of students and given again to the group at different times so the results will be the same.

\section{Types of Tests}

1. Based on the number of students
a. Individual tests
b. group tests.

2. Based on the preparation

a. the teacher-made test; tests arranged to produce information needed by the teacher.

b. standardized tests; tests are used to measure students' abilities and are used to predict future learning success.

3. Based on how it is implemented

a. Written test; is a test conducted by students answering item questions in writing. Written tests are divided into essay tests and objective tests.

b. Oral test; is a test that uses verbal language that aims to assess the ability of students' reasoning.

c. Test of deed; is a demonstration test.

\section{Knowledge Evaluation Test}

The assessment of knowledge at the unit level requires special formulation which is categorized as follows;

1. Questions about facts.

Questions for memory, ask questions about facts, know facts. For understanding, ask to explain in your own words.

2. Questions about concepts

Questions for memory, ask about examples and formulate definitions. For understanding, ask to classify examples.

3. Questions about procedures

For memory, ask about how to formulate the steps and the correct sequence. For understanding, ask about explaining the key points that govern effective behavior.

4. Questions about principles

Memory questions, ask about the formulation of rules or sets of rules. For understanding, ask about application examples. 


\section{Cognitive Test Construction}

Many written tests are considered sufficient to evaluate a goal. The teacher must be sure that the test material in the form of items can be used as an accurate evaluation tool.

1. Writing items

Thorndike and Hagenreveal some instructions in making test questions.

2. ReviewingItems

A teacher who has compiled questions shouldreview again to find out which items are incorrect.

3. Data Collection and Test Management

Collecting data into test material is a direct procedure. The execution of test items should start from the easiest to the most difficult by considering time. In addition, teachers must also be sure that students can do well. The time provided is also sufficient so that students get enough opportunities to do the test as well as possible.

4. Interpreting Assessment Results

The test used in evaluating the results is a score. This score provides information about the smooth teaching and learning. If it produces a low number, the teacher quickly looks for the cause to make improvements.

\section{CONCLUSION}

From the description above, it can be concluded that what is meant by evaluation is a process relating to gathering information that allows to determine the level of teaching progress and how to do good in the future times. This is supported by an understanding of the function and purpose of the evaluation, types of evaluation, evaluation principles, and evaluation techniques.

On that basis the ability to develop evaluations is a must for learning designers. As a measure of student success in achieving competence, an evaluation tool in the form of learning outcomes or the Benchmark Reference Assessment (PAP) is needed which is set out in the test development guidelines, test criteria, types of tests, and test construction.

\section{REFERENCES}

Abdul Mujib \& Jusuf Mudzakir, , 2008. Ilmu Pendidikan Islam,Jakarta: Kencana. Abdul Mujib dan Jusuf Mudzakkir, , 2008. Ilmu Pendidikan Islam, Jakarta:

Kencana Prenada Media Group.

Abudin Nata, Filsafat Pendidikan Islam, Jakarta: Gaya Media Pratama, 2005. Abudin Nata, , 2010. Ilmu Pendidikan Islam, Jakarta: Kencana Prenada Media Group. 
Abudin Nata, , 2008. Manajemen Pendidikan, Mengatasi Kelemahan Pendidikan Islam di Indonesia,Jakarta: Prenada Media Group.

Al-Rasyidin dkk, , 2005. Filsafat Pendidikan Islam Pendekatan Historis, teoritis dan Praktis, Jakarta : Ciputat Press.

Armai Arief, , 2002. Pengantar Ilmu dan Metodologi Pendidikan Islam, Jakarta: Ciputat Pers.

Hasan Langgulung, , 1989.Manusia dan Pendidikan Suatu Analisa Psikologi dan Pendidikan, Jakarta: Pustaka Al-Husna.

John M. Echols dan Hassan Shadily, Kamus Inggris-Indonesia.

M. Arifin, , 2009. Ilmu Pendidikan Islam, Tinjauan Teoritis dan Praktis Berdasarkan Pendekatan Interdisipliner, Jakarta: Bumi Aksara.

Hamalik, Oemar. 2011. Perencanaan Pengajaran Berdasarkan Pendekatan

Sistem. Jakarta : PT Bumi aksara.

Sanjaya, Wina. 2008. Perencanaan dan Desain Sistem Pembelajaran. Jakarta :

Kencana Prenadamedia Group. 